\title{
Penerapan Strategi Contextual Teaching and Learning untuk Meningkatkan Keaktifan Belajar Siswa pada Mata Pelajaran Fikih di MTs. Al-Ikhlas Mentigi
}

\author{
Haulid \\ MTs. Al-Ikhlas Mentigi, Kabupaten Lombok Utara - Provinsi NTB \\ *Corresponding Author. Email: haulidhaulid@gmail.com
}

\begin{abstract}
This study aims to describe the increase in student learning activity through the application of CTL (contextual teaching and learning) strategies. This research method uses classroom action research which is carried out in 2 cycles. Each cycle consists of planning, implementing actions, observing, and reflecting. The subjects of this study were 27 MTs class VII students. Al-Ikhlas Mentigi. The research instrument uses observation and tests, while the data analysis technique uses qualitative and quantitative descriptive analysis. The results of this study indicate that the application of the CTL (contextual teaching and learning) strategy is proven to increase learning activity which has an impact on student learning outcomes in Fiqh subjects. In addition, students feel happy about this learning strategy, this is manifested by the growing sense of togetherness in the group, the class atmosphere becomes more lively and there is a new experience for students to conduct a simple analysis of a problem that arises around them.
\end{abstract}

Abstrak: Penelitian ini bertujuan untuk mendeskripsikan peningkatan keaktifan belajar siswa melalui penerapan strategi CTL (contextual teaching and learning). Metode penelitian ini menggunakan penelitian tindakan kelas yang dilaksanakan dalam 2 siklus. Setiap siklus terdiri dari perencanaaan, pelaksanaan tindakan, observasi, dan refleksi. Subyek penelitian ini adalah siswa kelas VII sebanyak 27 MTs. Al-Ikhlas Mentigi. Instrumen penelitian menggunakan observasi dan tes, sedangkan teknik analisis datanya menggunakan analisis deskriptif kualitatif dan kuantitatif. Hasil dari penelitian ini menunjukkan bahwa penerapan strategi CTL (contextual teaching and learning) terbukti dapat meningkatkan keaktifan belajar yang berdampak pada hasil belajar siswa pada mata pelajaran Fiqih. Selain itu siswa merasa senang terhadap strategi pembelajaran ini, hal ini terwujud dengan tumbuhnya rasa kebersamaan dalam kelompok, suasana kelas menjadi lebih hidup dan adanya pengalaman baru bagi peserta didik untuk melakukan analisis sederhana terhadap suatu permasalahan yang timbul di sekeliling mereka.

\author{
Article History \\ Received: 02-08-2021 \\ Revised: $18-08-2021$ \\ Accepted: 09-09-2021 \\ Published: 05-10-2021 \\ Key Words: \\ Contextual Teaching and \\ Learning, Learning \\ Activity.
}

\section{Sejarah Artikel}

Diterima: 02-08-2021

Direvisi: 18-08-2021

Disetujui: 09-09-2021

Diterbitkan: 05-10-2021

\section{Kata Kunci: \\ Contextual Teaching and Learning, Keaktifan Belajar.}

How to Cite: Haulid, H. (2021). Penerapan Strategi Contextual Teaching and Learning untuk Meningkatkan Keaktifan Belajar Siswa pada Mata Pelajaran Fikih di MTs. Al-Ikhlas Mentigi. Jurnal Paedagogy, 8(4), 552559. doi:https://doi.org/10.33394/jp.v8i4.4101

https://doi.org/10.33394/jp.v8i4.4101

This is an open-access article under the CC-BY-SA License.

\section{Pendahuluan}

Pendidikan adalah salah satu penentu kualitas kehidupan berbangsa dan bernegara. Penataan pendidikan yang bermutu dan baik sangat mempengaruhi kemajuan suatu bangsa. Untuk mencapai hal itu pendidikan harus aktip sesuai perkembangan zaman. Salah satu usaha yang dilakukan pemerintah untuk memperbaiki mutu pendidikan nasional adalah dengan penyempurnaan kurikulum, yang istilahnya sudah tidak asing lagi yakni Kurikulum 13 (K.13). Selama ini hasil pendidikan hanya tampak dari kemampuan siswa dalam menghafal fakta-fakta, sehingga mereka seringkali tidak memahami substansi materi yang diperolehnya (Degeng, 2006; Manurung, 2021). Siswa belum mampu menghubungkan antara apa yang 
mereka pelajari dengan bagaimana pengetahuan itu dipergunakan. Siswa masih kesulitan untuk memahami dan menggunakan sesuatu yang abstrak dan metode ceramah. Mereka sangat butuh konsep-konsep yang berhubungan dengan tempat dan masyarakat umumnya dimana mereka akan hidup dan bekerja. Ada kecenderungan dalam dunia pendidikan dewasa ini untuk kembali pada pemikiran bahwa anak akan belajar lebih baik jika lingkungan diciptakan secara alamiah. Belajar akan lebih bermakna jika anak mengalami sendiri apa yang di pelajarinya.

Pembelajaran yang berorientasi target penguasaan materi terbukti berhasil dalam kompetisi "mengingat" jangka pendek, tetapi gagal dalam membekali anak memecahkan persoalan dalam kehidupan jangka panjang. Dan itulah yang terjadi di kelas-kelas sekolah kita, termasuk siswa Kelas VII MTs. Al-Ikhlas Mentigi. Metode belajar yang digunakan masih dominan dengan teknik menghafal daripada memahami substansi materinya. Strategi kontekstual CTL (contextual teaching and learning) adalah suatu strategi pengajaran yang dari karakteristiknya memenuhi harapan itu. Sekarang ini pembelajaran dan pengajaran konstektual menjadi tumpuan harapan para ahli pendidikan dan pengajaran dalam upaya "menghidupkan" kelas secara maksimal. Kelas yang hidup diharapkan dapat mengimbangi perubahan yang terjadi di luar sekolah yang demikian cepat.

Ada sejumlah alasan mengapa pembelajaran konstektual dikembangkan sekarang ini. Sejumlah alasan tersebut dapat dikemukakan sebagai berikut (Abdurrahman \& Bintoro, 2000; Sungkowo; 2003; Asmawati, 2018; Burengge, 2020):

1. Penerapan konteks personal meningkatkan ketrampilan komunikasi, akan membantu lebih banyak siswa untuk secara penuh terlibat dalam kegiatan pendidikan dan berdaya guna di lingkungan masyarakat.

2. Penerapan konteks ekonomi akan berpengaruh terhadap peningkatan kesejahteraan sosial

3. Penerapan konteks politik meningkatkan pemahaman siswa tentang berbagai isu yang dapat berpengaruh terhadap masyarakat.

4. Penerapan konteks budaya dalam pengembangan silabus, penyusunan buku pedoman guru, dan buku teks akan mendorong sebagian besar siswa untuk tetap tertarik dan terlibat dalam kegiatan pendidikan.

5. Penerapan konteks sosial dalam pengembangan silabus, penyusunan buku pedoman, dan buku teks yang berguna untuk mendiskusikan berbagai isu yang dapat berpengaruh terhadap perkembangan masyarakat

Adapun penelitian ini bertujuan untuk mendeskripsikan peningkatan keaktifan belajar siswa melalui penerapan strategi CTL (contextual teaching and learning) pada mata pelajaran Fiqih di MTs. Al-Ikhlas Mentigi Kabupaten Lombok Utara.

\section{Metode Penelitian}

Peneltian ini menggunakan metode penelitian tindakan kelas yang dilaksanakan di MTs. Al-Ikhlas Mentigi pada siswa kelas VII Semester Genap Tahun Pelajaran 2020-2021. Subyek penelitian berjumlah 27 orang dengan rincian 14 laki-laki 13 perempuan. Penelitian ini dilaksanakan dalan 2 siklus. Siklus pertama dilaksanakan dua kali pertemuan dan siklus kedua dilaksanakan satu kali pertemuan. Setiap siklus dilaksanakan dalam 4 tahapan, yaitu 1) perencanaaan, 2) pelaksanaan tindakan, 3) observasi, dan 4) refleksi.

Sumber data penelitian diperoleh dari siswa dengan jenis data berupa data kualitatif (aktifitas siswa) dan kuantitatif (pennguasaaan konsep siswa). Data aktivitas siswa diambil dengan teknik obervasi dengan menggunakan lembar observasi pada setiap pertemuan, sedangkan data penguasaan konsep siswa dari setiap siklus di peroleh dengan memberkan tes 
berbentuk pilihan ganda sebanyak 10 butir. Data aktivitas siswa diperoleh dari hasil lembar obsrvasi dianalisis secara kuantitatif dengan rumus ;

$$
\mathrm{AP}=\frac{2 \mathrm{p}}{2 \mathrm{p}} \times 100 \%
$$

Keterangan ;

AP : Nilai persen yang dicari

$\sum \mathrm{p} \quad$ : Aktivitas siswa

$\sum \mathrm{p} \quad$ : Jumlah siswa

Adapaun Kreteria menentukan standar persentasi aktivitas ,siswa dapat di lihat pada table berikut ini

Tabel.1. Kriteria Aktivitas Siswa

\begin{tabular}{|l|l|}
\hline \multicolumn{1}{|c|}{ Aktivitas (\%) } & \multicolumn{1}{c|}{ Kriteria } \\
\hline $76-100$ & Sangat baik \\
\hline $51-75$ & Baik \\
\hline $26-50$ & Cukup \\
\hline$\leq 25$ & Kurang \\
\hline
\end{tabular}

(Sumber : Trianto, 2010)

\section{Hasil Penelitian dan Pembahasan \\ Deskripsi Siklus Pertama \\ Perencanaan}

Sebelum melaksanakan tindakan, peneliti melakukan perencanaan sebagai berikut:

1) Diskusi dengan guru pamong untuk memilih kelas yang akan diteliti

2) Guru mata pelajaran membantu peneliti sebagai pengamat dalam kegiatan pembelajaran dengan memantau peneliti dalam melakukan KBM.

3) Membuat Rencana Pembelajaran dan menyusun langkah-langkah pembelajaran yang logis dan sistematis

4) Dalam proses belajar mengajar peneliti menerapkan strategi CTL (contextual teaching and learning), yang penerapannya sebagai berikut:

Langkah I

a) Peneliti menjelaskan tujuan pembelajaran

b) Peneliti menggali pengetahuan siswa terhadap materi yang diajarkan

c) Peneliti membagi siswa menjadi 5 kelompok untuk sharing dan kemudian berdiskusi

Langkah II

a) Peneliti mempersilahkan siswa yang telah terbagi dalam kelompok untuk berdiskusi tentang materi yang diajarkan

b) Setelah berdiskusi, setiap kelompok mempresentasikan hasil diskusinya di depan kelas.

c) Kelompok yang lain dipersilahkan untuk menyanggah ataupun mengkritik pendapatnya.

Langkah III

a) Peneliti mengevaluasi jalannya kegiatan pembelajaran

b) Peneliti yang juga sebagai guru menambahkan beberapa penjelasan tentang materi

Pertemuan Pertama (20 Januari 2020) 


\section{Tahap awal}

1) Salam Pembuka

2) Guru melakukan apersepsi terhadap materi yang sudah diberikan

\section{Tahap inti}

Pre Activity

1) Peneliti menjelaskan tentang pokok materi yang akan diajarkan

2) Peneliti membagi siswa menjadi 5 kelompok diskusi

3) Peneliti membagi tugas kepada masing-masing kelompok diskusi untuk membahas tentang materi yang disampaiakan.

Whilst Activity

1) Siswa melakukan diskusi dengan kelompoknya

2) Setelah selesai diskusi, masing-masing kelompok mempresentasikan hasil diskusinya

3) Kelompok yang lain menanggapi, dan bertanya.

4) Peneliti menjadi fasilitator selama kegiatan belajar berlangsung.

Post Activity

1) Peneliti mengevaluasi jalannya kegiatan belajar

2) Peneliti yang juga sebagai guru menambahkan beberapa penjelasan tentang materi yang sedang dibahas.

\section{Tahap akhir}

1) Peneliti memberi feed back kepada siswa dan memberi kesempatan untuk bertanya

2) Salam penutup

\section{Refleksi}

Pada siklus pertama peneliti masih belum melihat respon siswa terhadap diskusi yang dilakukan, sehingga jalannya diskusi tidak berjalan efektif. Oleh karena itu pada pertemuan berikutnya peneliti memberikan motivasi kepada siswa agar dapat melakukan diskusi dengan baik dan tertib dan memilih strategi CTL (contextual teaching andlearning) untuk mendapatkan hasil yang maksimal. Setelah dipersiapkan rencana pembelajaran dan metode yang akan dipakai, maka proses pembelajaran dilaksanakan sesuai dengan rencana pembelajaran dan menerapkan strategi dan metode yang telah ditetapkan.

\section{Pertemuan Kedua (03 Februari 2020)}

\section{Tahap awal}

1) Salam pembuka

2) Guru melakukan apersepsi terhadap materi yang sudah diberikan

\section{Tahap Inti}

Pre Activity

1) Peneliti menjelaskan pokok materi yang akan diajarkan

2) Peneliti menggali pengetahuan siswa tentang materi yang akan dipelajari dan dihubungkan dengan kehidupan sehari-hari

3) Peneliti membagi siswa menjadi 6 kelompok diskusi

4) Peneliti membagi tugas kepada masing-masing kelompok yang membahas tentang hal-hal yang berkenaan dengan ahli waris yang tidak jelas dan dihubungkan dalam kehidupan sehari-hari.

Whilst Activity

1) Siswa melakukan diskusi dengan kelompoknya

2) Setelah dibahas di kelompok masing-masing, setiap kelompok mempresentasikan hasil pembahasan di depan kelas, sedang kelompok yang lain menanggapi, menyela, atau bertanya 
3) Peneliti memberi kesempatan siswa untuk mengaitkan pelajaran yang baru dia tanyakan dan diperolehnya pada hari itu dengan kehidupan sehari-hari.

4) Peneliti menjadi fasilitator selama kegiatan belajar mengajar berlangsung

Post Activity

1) Peneliti mengevaluasi jalannya kegiatan belajar

2) Peneliti yang juga sebagai guru menambahkan beberapa penjelasan tentang beberapa hal yang tidak jelas.

\section{Tahap Akhir}

1) Peneliti memberi feed back kepada siswa dan memberi kesempatan untuk bertanya

2) Salam penutup

\section{Hasil Pengamatan}

Hasil pengamatan peneliti pada proses belajar mengajar pada siklus ini, siswa terlihat antusias, aktif dan kreatifitas siswa lebih bervariasi, hal ini dikarenakan siswa lebih siap dengan strategi dan metode yang diterapkan dalam pembelajaran. Peningkatan keaktifan siswa terhadap materi terlihat dari aktifitas selama kegiatan berlangsung, yakni siswa aktif untuk berdiskusi dan aktif untuk bertanya tentang materi yang belum dipahami. Selain itu siswa bisa mengaitkan pengetahuan yang dipahami dengan kehidupan sehari-hari.

\section{Refleksi}

Penerapan strategi CTL (contextual teaching and learning) dapat membuat siswa lebih bersemangat mengikuti proses belajar mengajar, hal ini dikarenakan siswa lebih menguasai pengetahuan yang telah dia pahami karena merupakan hasil dari usahanya sendiri dan lebih terdorong untuk mengetahui pengetahuan Fikih lebih dalam.

\section{Pembahasan}

Salah satu cara meminimalisir kebiasaan siswa pasif terhadap pelajaran adalah dengan menerapkan strategi CTL (Contextual Teaching and Learning) dengan metode cooperative learning. Cara ini merupakan inovasi baru dalam KBM, yakni ingin merubah menjadi student orientend, yakni pelajaran yang lebih memberdayakan murid (Nurhadi, 2003; Sungkowo, 2003; Suharni, 2020; Luthfi et al., 2021). Penelitian tindakan kelas ini dilaksanakan dengan tujuan untuk mengetahui peningkatan aktivitas dan penguasaan konsep siswa terhadap materi sesuai dengan fase (sintak) pembelajaran yaitu; a) fase engagement, guru menggali minat siswa.b) fase explanation, siswa berdiskusi dan bekerja sama dalam kelompok kecil tampa pengajaran langsung dari guru untuk mempelajari konsep dari berbagai sumber atau referensi. c) fase explanation, siswa menjelaskan hasil diskusinya dengan kata-kata mereka sendiri, menunjukkan bukti dan klarifikasi dari penjelasan mereka serta menyimak tanggapan atau penjelasan siswa lain dengan kritis. d) fase elaboration, siswa menrapkan konsep dan keterampilan yang telah mereka kuasai dalam situasi yang baru dengan memberikan soal-soal pemecahan masalah. e) fase evaluation, siswa diberikan untuk mengetahui sejauh mana siswa mencapai kopetensi atau pemahaman konsep tentang materi yang sudah di pelajari,berikut dipaparkan hasil penelitian setiap siklus.

Hasil observasi aktivitas selama berlangsungnya proses pembelajaran menunjukkan terjadi peningkatan persentase aktivitas belajar dari siklus I ke siklus II. Berikut rekapitulasi persentase peningkatan aktivitas siswa dari siklus I ke siklus II dalam table berikut:

Tabel.1. Rekapitulasi Persentase Peningkatan Aktivitas Siswa

\begin{tabular}{|l|c|c|c|}
\hline No & Indikator Aktivitas & $\begin{array}{c}\text { Siklus } \\
\text { I }\end{array}$ & $\begin{array}{c}\text { Siklus } \\
\text { II }\end{array}$ \\
\hline 1 & Berdiskusi dan bekerjasama Kelompok melalaui telaah literatur & 75 & 90 \\
\hline
\end{tabular}




\begin{tabular}{|l|l|c|c|}
\hline 2 & Bertanya,mengusulkan atau memecahkan masalah & 33 & 77 \\
\hline 3 & Melakukan pembuktian terhadap konsep yang diajukan kelompok & 50 & 70 \\
\hline 4 & Memberikan Respon terhadap pertanyaan guru & 40 & 72 \\
\hline 5 & Menarik kesimpulan hasil diskusi bersama-sama & 73 & 88 \\
\hline 6 & $\begin{array}{l}\text { Menerapkan konsep untuk menyelesaikan soal-soal pemecahan } \\
\text { masalah }\end{array}$ & 68 & 91 \\
\hline 7 & Mengikuti Evaluasi dan merepleksi pembelajaran & 70 & 80 \\
\hline 8 & Mengkaji Konsep dari berbagai sumber dalam kelompok & 70 & 85 \\
\hline 9 & Menjelaskan hasil temuan kelmok dalam diskusi klasikal & 46 & 63 \\
\hline 10 & Menunjukkan minat dan rasa ingin tahu terhadap pokok bahasan & 75 & 94 \\
\hline & kreteria & 60 & 81 \\
\hline & Baik & $\begin{array}{l}\text { Sangat } \\
\text { baik }\end{array}$ \\
\hline
\end{tabular}

Hasil evaluasi tiap akhir siklus terhadap penguasaan konsep siswa dari siklus I ke Siklus II mengalami peningkatan.berikut di sajikan rekapitulasi hasil evaluasi tersebut dalam table berikut ini.

Tabel 3. Rekapitulasi Data Setiap Siklus

\begin{tabular}{|l|l|c|c|}
\hline No & Nilai tertinggi & Siklus I & Siklus II \\
\hline 2 & Nilai tertinggi & 75 & 94 \\
\hline 3 & Nilai terendah & 51 & 66 \\
\hline 4 & Rerata Kelas & 82,94 & 86,63 \\
\hline 5 & Tuntas (\%) & 81,48 & 88,88 \\
\hline 6 & Tidak Tuntas (\%) & 19,52 & 11,12 \\
\hline 6 & Jumlah siswa yang mengikuti Tes & 27 & 27 \\
\hline
\end{tabular}

Tabel tersebut menunjukkan bahwa penguasaan konsep siswa terhadap materi dengan pokok bahasan Ketentuan Shalat Jumat terjadi peningkatan setiap siklusnya, baik untuk nilai tertinggi, nilai terendah, maupun rerata kelas. nilai tertinggi pada siklus I sebesar 75 meningkat menjadi 94 pada siklus II, nilai terendah pada silus I sebesar 51 meningkat menjadi 66 pada siklus II, rerata kelas pada silus I sebesar 82,94 meningkat menjadi 86,63 pada siklus II, kemudian ketuntasan kelas dari siklus I ke siklus II dari 81,48 \% (27 orang) menjadi 88,88\% (27 Orang). Hal ini karena siswa semakin termotivasi mengikuti pembelajaran dan mampu menyelesaikan segala persoalan yang dihadapi, baik permasalahan yang ditemukan langsung saat proses pembelajaran maupun saat menyelesaikan soal-soal evaluasi yang di berikan ,maka Secara keseluruhan hasil dari penelitian ini menunjukkan bahwa model menerapkan strategi CTL (Contextual Teaching and Learning) dengan metode cooperative learning mampu meningkatkan aktivitas dan penguasaan konsep siswa terhadap materi pembelajaran pada pokok bahasan Ketentuan Shalat Jumat mata pelajaran Fikih kelas VII pada Semster Genap Tahun Pelajaran 2020-2021.

\section{Kesimpulan}

Kesimpulan hasil penelitian ini bahwa penerapan strategi CTL (Contextual Teaching And Learning) dengan metode cooperative learning pada proses belajar mengajar di Kelas VII MTs. Al-Ikhlas Mentigi telah dapat meningkatkan keaktifan siswa terhadap mata pelajaran Fikih. Dengan adanya peningkatan keaktifan siswa ini, dapat terlihat motivasi dan keterlibatan siswa dalam proses belajar mengajar, selain itu hasil belajar siswa juga cukup memuaskan. 


\section{Saran}

Ada beberapa saran konstruktif yang diharapkan dapat mendukung kualitas proses belajar mengajar pada mata pelajaran Fiqih di VII MTs. Al-Ikhlas Mentigi pada khususnya dan seluruh lembaga pendidikan pada umumnya, diantaranya: (1) Dalam setiap pembelajaran, perlu adanya strategi, metode, maupun teknik pembelajaran yang dapat menarik perhatian dan minat siswa, yang hendaknya dipersiapkan oleh seorang guru sebelum melaksanakan kegiatan belajar mengajar. Perlu adanya perhatian guru yang intens terhadap siswa terkait dengan proses belajar mengajar sehingga siswa tidak merasa bosan ataupun jenuh dalam proses belajar mengajar.

\section{Daftar Pustaka}

Abdurahman dan Bintoro. (2000). Memahami dan Menangani Siswa Dengan Problematika Belajar. Jakarta: Depdiknas.

Arikunto S, Suhardjono, Supardi. (2003). Penelitian Tindakan Kelas. Jakarta : Bumi Aksara. Asmawati, A. (2018). Penerapan Metode Contextual Teaching And Learning Tipe Modeling untuk Meningkatkan Hasil Belajar Siswa pada Mata Pelajaran Agama Islam dan Budi Pekerti di SMAN 3 Mataram. Jurnal Kependidikan: Jurnal Hasil Penelitian dan Kajian Kepustakaan di Bidang Pendidikan, Pengajaran dan Pembelajaran, 4(1), 1-8. doi:https://doi.org/10.33394/jk.v4i1.895

Burengge, S. (2020). Penerapan Model Pembelajaran Kooperatif Tipe STAD dengan Pendekatan Kontekstual bagi Siswa SDN 7 Tentena Sulawesi Tengah. Jurnal Paedagogy, 7(4), 275-280. doi:https://doi.org/10.33394/jp.v7i4.2832

Degeng I Nyoman S. (2006). Teori dan Konsep Belajar. Surabaya: Program Pascasarjana Universitas PGRI Adibuana.

Depdiknas. (2005). Peraturan Pemerintah Republik Indonesia Nomor 19 Tahun 2005 tentang Standar Nasional Pendidikan, Jakarta: Mendiknas.

Killen, Roy. (1998). Efektive Teaching Strategies, Katoomba NSW: Social Science Press

Kurikulum 2004 Sekolah Menengah Pertama dan Madrasah Tsanawiyah. (2003). Standar Kompetensi, Jakarta : Departemen Pendidikan Nasional.

Lambas, dkk, (2004). Materi Pelatihan Terintegrasi Buku 3, Modul 25, Jakarta

Luthfi, M., Huda, C., \& Susanto, J. (2021). Penerapan Model Pembelajaran Discovery Learning Untuk Meningkatkan Keaktifan Belajar Siswa pada Pembelajaran Tematik Kelas V Tema 8 di SD Negeri 1 Selo Kabupaten Grobogan Jawa Tengah. Jurnal Paedagogy, 8(3), 422-430. doi:https://doi.org/10.33394/jp.v8i3.3902

Manurung, R., Sadjiarto, A., \& Sitorus, D. (2021). Aplikasi Google Classroom sebagai Media Pembelajaran Online dan Dampaknya Terhadap Keaktifan Belajar Siswa pada Masa Pandemi Covid-19. Jurnal Kependidikan: Jurnal Hasil Penelitian dan Kajian Kepustakaan di Bidang Pendidikan, Pengajaran dan Pembelajaran, 7(3), 729-739. doi:https://doi.org/10.33394/jk.v7i3.3853

Muslimin Ibrahim. (2000). Pembelajaran Kooperatif. Surabaya: Program Pascasarjana Unesa.

Nurhadi, Yasin B, Senduk, A.G. (2003). Pembelajaran Kontekstual (Contextual Teaching and Learning/CTL) dan Penerapannya dalam KBK, Malang : Penerbit UM.

Nurhadi. (2002). Pendekatan Kontekstual (Contextual Teaching and Learning/CTL), Jakarta : Departemen Pendidikan Nasional. 
Suharni, S. (2021). Meningkatkan Keaktifan dan Hasil Belajar Melalui Penerapan Model Pembelajaran Wide Game pada Peserta Didik Kelas VIID SMP Negeri 13 Tegal. Jurnal Paedagogy, 8(1), 87-92. doi:https://doi.org/10.33394/jp.v8i1.3278

Sungkowo. (2003). Pendekatan Kontekstual, Jakarta : Departemen Pendidikan Nasional Dirjen Pendidikan Dasar dan Menengah, Direktorat Pendidikan Lanjutan Pertama.

Trianto. (2010). Model Pembelajaran Inovatif-Progresif Konsep, Landasan, dan Implementasi Pada Kurikulum Tingkat Satuan Pendidikan (KTSP). Jakarta: Kencana 